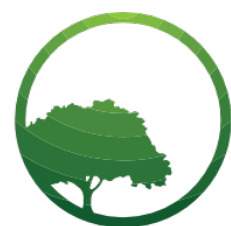

Business \& Social Science IJRBS

\section{Research in Business and Social Science}

IJRBS Vol 6 No 6, ISSN: 2147-4478

Contents available at www.ssbfnet.com/ojs

Doi: 10.20525ijrbs.v6i6.831

\title{
Disaster as Business Risk in SME: An Exploratory Study
}

\section{Anton A Setyawan}

Faculty of Economics and Business, Muhammadiyah University of Surakarta, Surakarta, Indonesia, +62 271717417

\section{Muzakar Isa}

Faculty of Economics and Business, Muhammadiyah University of Surakarta, Surakarta, Indonesia, +62 271717417

\section{Farid Wajdi}

Faculty of Economics and Business, Muhammadiyah University of Surakarta, Surakarta, Indonesia, +62 271717417

\section{Syamsudin}

Faculty of Economics and Business, Muhammadiyah University of Surakarta, Surakarta, Indonesia, +62 271717417

\section{Abstract}

The concept of business risk has been extended to several new concepts. Disaster, disease, social unrest and terrorism are emerging as part of business risks. This study aim is to explore classification of disaster risk in micro, small and medium enterprises (MSME). This study explains factors and risk perception of disaster prevention and reduction. The study based on survey, which involved 315 MSMEs, focus group discussion and in-depth interview with several key informants. We use content analysis as a basic tool in the data analysis process, with descriptive statistic to complete information findings in the study. Unit analysis of this study are MSME industries, they are batik and textile, furniture and handy-craft and food industry. The result shows that they are interconnectedness between financial institution, local governance and MSME in the disaster risk management model. Each party has obligations in conducting preparedness of disaster and risk protection procedures for disaster risk management. We also find that there is still very low risk perception among MSME in Surakarta. This could be a potential problem when the disaster risk management should be implemented in MSME business.

Key words: Disaster Risk, Risk Protection, Disaster Risk Management

JEL classification: M20, G32 


\section{Introduction}

Discussion of disaster management is limited in the process of disaster prevention of casualties, facilities and infrastructure (Zaitri, 1996). The process of rehabilitation is also discussed in disaster reduction as a part of disaster management (Perry, 2007; Paton, 2003; Marshall et al., 2015). Keating et al., (2016) and Paton (2003) in his publication mention that promoting disaster preparedness for household and institution is important, however level of disaster preparedness is remaining low. Kumar and Newport (2007) in their work propose that in the time of disaster there should be institutional preparedness to prevent any further damage for the poor. It related with how the poor should protect their job sustainability. Micro, small and medium enterprises (MSME) are special form of business, which related with the poor to overcome their financial sustainability. In the time of disaster, MSME suffers major destruction. Their business collapse and production process is being halt. Unfortunately, this condition has been considered as force majeure, which gives a disadvantage situation for MSME. For example, during Merapi 2006 eruption in Indonesia, more than 200 MSME located in Klaten, Magelang and Boyolali in Jawa Tengah Province suffers IDR 39 billion lost of their business. However, there still dispute about who should gives warranties of those lost, since MSME do not prepare for disaster, while government has limited budget. The Commission on Climate Change and Development proposed a policy of risk transfer and insurance as a part of disaster reduction policy which include risk protection for the poor (Arnold, 2006). Risk transfer and insurance could be included in disaster risk management for SME.

Surakarta is a city which has a wide population of MSME concentrates on three different industry, they are batik and textiles, furniture and handy-craft and food industry. On the other hand BNPB (National Board of Disaster Management) has considered the city vulnerable toward disasters. National Plan of Disaster Mitigation Documents 2010-2014 issued by BNPB mentions that Surakarta are vulnerable toward three different kinds of disaster, they are erosion, drought and urban fire disaster. We have presumption that MSME in Surakarta do not have disaster risk protection. This presumption based on the fact that most MSME in Surakarta concentrates on surviving their business, while disaster risk has not been considered as threat. Kumar and Newport (2007) and Ainuddin and Routray (2012) suggest that risk protection and risk preparedness of an institution should be a part of disaster risk management.

This research aim is to explores and identify disaster risk management which includes perception of risk, risk protection and risk preparedness for MSME. Perception of risk related with how MSME business perceived disaster as part of business risk and its effect to their business. Risk protection associates with MSME action to minimize negative effects of disaster to their business. The design of this research is exploratory research with combination of data collection methods. We use survey, in-depth interview and focus group discussion to collect the data. We decide to use this approach to uncover SME disaster risk management model.

\section{Literature Review}

Smith and Fischbacher (2009) analyze changing the nature of risk and risk management. Business institutions have to deal with new forms of business risks. It has different characteristic such as terrorism, pandemic flu, global crisis and disaster. Smith and Fischbacher (2009) state conventional approach of risks has new challenges, due to new form of business risks. These new form of business risks has several characteristics. First, it lack of a priori evidence which make it more unpredictable. Second, the effect of risk is large and it effect on further damage or crises. Third, technical aspects of these risks are very complicated resulted increasing possibilities of failure in the process of assessment and evaluation. 
Business risk has several aspect and definitions. Business risk in the terms of general definitions have various meaning. Kuritzkes and Schuermann (2006) define business risk as residual risk left after all risks has been identified. Strategic management has different definition of business risk. In the context of strategic management, business risk refers to making incorrect strategic choices (Alexander, 2005). Business related with uncertainty, since it always facing conditions of dynamic business cycle. According to Doff (2008), there are two source of uncertainty in business risk, they are competitive environment and adaptation to changes.

Disaster is uncertainty in nature and it effect directly to business. Atmanand (2003) states disaster classifies force majeure which needs adjustment in the process of risk protection procedure. However, to be consistent with Smith and Fischbacher (2009) approach, disaster is new kind of business risk. Paradine (1995) suggests business organization should include disaster in their contingency plan. Specifically, contingency plan of business which include disaster should be a part of risk management of business organization. Cooper (2000) in his article of banking risk management described risk as hazard or threat when it related with negative events, such as system failure, reputation damage and disaster. This description consistent with Atmanand (2003) who classifies disaster as force majeure.

Disaster risk management of business organization consists of risk management and insurance. Those two elements are risk protection from disaster of business organizations. Paradine (1995) specifies the difference between risk management and insurance. Risk management for business organization is an act of prevention or optimal use of resource to minimize risk. On the other hand, insurance helps business organization recovering themselves of loss due to disaster. Insurance have nothing to do with preventing risk, it helps business organization minimizing financial loss. Business organization should arrange their disaster risk management instead of just paying insurance polis for their assets. Linnerooth-Bayer and Hochrainer-Stigler (2015) has developed disaster management risk reduction by using financial instruments to provide disaster recovery fund. This procedure is very useful for business especially SME in developing countries with low ability to recover their business after disaster.

In term of business, disaster often included as force majeure which needs special treatment. Disaster should be considered as risk in business and it should be manage carefully. Paradine (1995) mentioned disaster could result business interruption. Business interruption means that all business activities from raw material inventory, production process, distribution and marketing activities are being halted (Paradine, 1995). Business institution should be prepared for disaster. Kumar and Newport (2007) find it is important for business institution to keep their liquidity in a disaster situation. Large and modern business institutions are prepared of disaster risk due to their knowledge and financial capability. Cochrane (2004) and Paradine (1995) give example of organization preparation of constructing disaster risk management, which include public and private institution. Most of those organizations have ability to transfer their risk whether by insurance or conducting safety operational procedure. However, MSME does not have such priorities, instead of creating disaster risk management procedures; this business institution concentrates on surviving their business. Ainuddin and Routray (2012) suggest community disaster preparedness as a basic to develop institutional disaster preparedness. Their research in Balochistan, Pakistan shows that community needs should match with institutional activities to build disaster preparedness for community. In their research local government fail to fulfill community needs in time of disaster since they conduct disaster response based on top down approach. Ainuddin and Routray (2012) conclude institutional preparedness of disaster should be build based on community preparedness and needs in time of disaster. This conclusion match with MSME condition. MSME especially micro businesses are more related with community than business 
organization. MSME is a special kind of business organization with different characteristic compare to other business organization. Pinho (2007) found MSME has a very flexible organizational structure and tend to operate in low cost activities. Supyuenyong et al. (2009) also found that SME ownership structure are dominated with personal owned companies. These characteristics explain the reason why MSME neglected disaster risk, since it might be expensive for them.

Preparing a disaster risk management model for MSME must be initiated with measuring economic loss. Cochrane (2004) suggests that assessment of economic loss from a disaster should reflect three kinds of losses; they are direct loss, iconic loss, environmental loss, indirect loss from interindustry effects, postponed impacts and offsets. Cochrane (2004) specifies each economic loss with these explanations: direct loss refers to property damage, either public or private property and also fatalities and injuries. Iconic lost are related with cultural assets and historical monuments damage which could effects on tourism. Environmental loss includes environmental damage or changes in the disaster area. Indirect loss from inter-industry effects is value chain interruption of industries in the disaster area or others area related with it. Postponed impacts are revenue loss of household which caused consumption decreasing. Offsets include rebuilding stimulus, survivor benefit payments and unemployment compensation. Measurement of each economic loss will be foundation of preparing disaster risk management for MSME.

MSME plays a significant role in Indonesia development. During 1997-1998 Indonesia financial crisis, MSME has proven tough and survive. It flexibility and low cost operation has save this country from further damage caused by crisis. Ikhsan (2004) claims the highest contributions of MSME in Indonesia is labor absorption. 73,53 million of Indonesia labor work in MSME, while there are only 28,52 million people join modern and big corporate. Tambunan (2008) show most of MSME in Indonesia concentrated in the urban area. Urban areas in Indonesia have a special condition in their condition. Surakarta is one of growing urban in Indonesia which has unique characteristic in it economic structure. MSME dominate number of business organizations in Surakarta. According to Surakarta Cooperation and Micro Small Mid Sized Business Office, there are 52.500 MSME businesses in this city. There are 4 types of business dominates MSME in Surakarta. They are batik, textiles, furniture and food industries. Table 1 shows basic indicators of those MSME industries. The 80 percent of MSME in Surakarta are owned by individuals, which left only 20 percent of them have legal status, such as CV or PT. 75 percent of MSME in Surakarta own 1-10 million IDR assets, with operating capital from 5 to 50 million IDR. 70 percent of MSME in Surakarta use their residence as their plant or store.

Tabel 1: Basic Indicators of Surakarta MSME

\begin{tabular}{|l|l|l|l|l|l|l|l|}
\hline No & Industries & Quantity & Investment & Production & \multicolumn{2}{l|}{} \\
\cline { 3 - 8 } & Unit & Labor & $\begin{array}{l}\text { Value IDR } \\
(000)\end{array}$ & Volume & Unit & Value IDR (000) \\
\hline $\mathbf{1}$ & $\begin{array}{l}\text { Batik dan } \\
\text { Produk Batik }\end{array}$ & 102 & 1,636 & $190,000.00$ & $3,258.00$ & Kd & $430,558,000.00$ \\
\hline $\mathbf{2}$ & $\begin{array}{l}\text { Tekstil dan } \\
\text { Produk Tekstil }\end{array}$ & 132 & 623 & $973,500.00$ & $953,370.00$ & $\mathrm{Bh}$ & $19,611,000.00$ \\
\hline $\mathbf{3}$ & Mebel & 114 & 523 & $496,000.00$ & $696,940.00$ & $\mathrm{Bh}$ & $18,949,500.00$ \\
\hline $\mathbf{4}$ & Shuttle Cocks & 10 & 70 & $200,000.00$ & $1,008,000.00$ & Dos & $15,000,000.00$ \\
\hline $\mathbf{5}$ & Makanan & 119 & 4,753 & $567,000.00$ & $4,373,538.00$ & $\mathrm{Kg}$ & $8,841,671.00$ \\
\hline
\end{tabular}

Source: BPS 2014 


\section{Research and Methodology}

This study employs a mixed method to answer the research question. We use mixed method approach because we try to analyze two different purposes in this study. Tashakkori and Teddie (1998) suggest that in order to answer two different purposes in the study or to get a deeper and broader perspectives researcher must use mixed method approach. In this study we use two different research methods, they are focused group discussion and surveys.

We conduct our first FGD in order to answer SME's owner perception of disaster risk and its effect to their business. The second FGD arranged with mainly purpose to developed model of disaster risk management for MSME. These FGDs involve 34 SMEs and their stakeholders in Central Java and Jogjakarta located in high risk disaster area. We also undertake survey involve 315 SMEs in Central Java and Jogjakarta to make an assessment of disaster impact to their business.

\section{Analysis}

\section{First FGD: Disaster Risk Perception and The Measurement}

First FGD involved 17 key informants from academic experts, local government, bank, insurance company and SME association. In the first FGD, we explore disaster risks perceptions and knowledge from our key informants. In general, our key informants realize that Indonesia is a country with high disaster risk, but they still in doubt when we informed to them that Surakarta classified as a city with several disaster risks.

In this discussion we found that disaster risk is not considered as an important issue in SME business. This attitude is a result of lack of knowledge about the issue. In the other hand, our key informant from expert gives us several suggestions on how to measure disaster risk. The result is we attach disaster frequency in disaster risk measurement.

\section{Survey: Assesment of Disaster Risk Perception and Its Impact of Disaster Risk to MSME Business}

This survey involved 315 MSME business, which included 102 textiles and batik business, 107 food businesses and 106 furniture and handicrafts business. The classification of SME refers to SME act No. 20/2008.

The measurement of the survey is disaster risk possibility questionare that contains of simple question about type of disaster that could occur during business process. Our findings in survey show that there are three kinds of disaster risks which considered by respondents, they are fire, climate change and floods. Fire has considered to be highest possible disaster in Surakarta's SME. Table 1 shows the result of statistic descriptive from teh survey.

Table2: Dsecriptive Statistic od Fire Risk

\begin{tabular}{|l|l|}
\hline Industries & Mean Scores of Fire Risks \\
\hline All (Food, Furniture and Batik) & 2,18 \\
\hline Food & 1,93 \\
\hline Furniture & 2,53 \\
\hline Batik & 2,11 \\
\hline
\end{tabular}

All industries have similar perceptions that fire is the most potential disaster that could negatively affect their business. Our furniture MSME respondents have experienced fire disaster in the middle 1990's and early 2000's. It explain their highest score of fire risks perceptions. Production process 
in this industry is very closed with fire risk, for example in the finishing step and wood processing. In batik industry, there are many flammable raw and supporting materials, such as fabric, paraffin and naphthol. Our respondents in batik industries aware that those materials could become source of disaster if they're not follow appropriate business process. Our respondents in food industries have low awareness of any kinds of disaster due to lack of experience in preventing one.

We are also ask our respondents about the impact of disaster to their business. Our measurement is assessment of business risks that may appear during business process if disaster happened. We develop questions about disaster impact in their business and they assess with rating scale from minimum impact to maximum impact. Table 3 shows the result of disaster impact to business process assessment.

Table 3: Disaster Impact to Business Process Assessment

\begin{tabular}{|l|l|}
\hline Business Process & Percentage \\
\hline Production tool and machinery & $31,68 \%$ \\
\hline Plant/factory & $24,75 \%$ \\
\hline Capital and access to capital & $21,78 \%$ \\
\hline Product & $12,87 \%$ \\
\hline
\end{tabular}

Production tool and machinery are part of business process that has been considered vulnerable from disaster. Based on furniture and batik industries experienced during a disaster (fire and floods), they have to suffer production halt for almost a year due to loss of their production tool. Plan and factory damaged are also have serious impact to their business, however the flexibility in changing plant due to small business volume and government assistance when this problem occured makes this process business aspect considered less important. Capital and access to capital are often become obstacles for MSME in normal conditions. This issue could be more serious in disaster. Our respondents rely their capital needs based on their own resources or family and relatives fund. When disaster occured, MSME do not have reserve resources for capital. MSME relies their access of capital to government when disaster occured. Government assistance to MSME in fulfilling capital requirementt ussualy in the form of debt reschedulling and debt swapt mechanism for those companies which have bank access. However, for un-bankable MSME ussually their capital requirement to business recovery have been fulfilled by government aid. Product damage also considered as important business process that could be constraints in time of disaster. Product damage has considered heavy loss for MSME, however most of our respondents are MSME wich rely their production process based on order. They do not have large inventory of products.

Our next step in the survey is to have an assessment of MSME risk anticipation. We develop question about MSME anticipation of business risks that may appear from disaster. Table 4 shows results of statistic descriptive of MSME business risks anticipation.

Table 4: MSME Disaster Risk Anticipations

\begin{tabular}{|l|l|}
\hline Risk Anticipations & Percentage \\
\hline Saving from business revenue & $40 \%$ \\
\hline Constructing safety procedure in business process & $35 \%$ \\
& \\
\hline Joint cooperation in risk sharing & $15 \%$ \\
\hline Buying insurance & $5 \%$ \\
\hline Others & $5 \%$ \\
\hline
\end{tabular}


MSME usually have saving some of their revenue to anticipate uncertainty in their capital loss. However, this saving is not specified for disaster risks but for general business risks. The idea of constructing safety procedure in their business process has been an awareness for our respondents. In furniture and batik industry this safety procedure contsruction has been conducted eventhough it still in the early stages.

Join cooperation in risk sharing is to strengthen MSME association to prepare and construct standard operation in business recovery after disaster. This anticipation has been an agenda for MSME association but there are few constraints in the process due to lack of disaster prevention and mitigation knowledge. Other way of risk sharing procedure is to buy disaster insurance. Small and middle companies in furniture and batik has earn this disaster insurance product but micro business does not have financial capability to have such insurance.

\section{Second FGD: Developing Risk Management Model for MSME}

In the second FGD, we invited 17 key informants but only 15 of them appeared in the discussion. In this FGD, we confirm our findings from survey and explored more deep information from key informants. We found that MSME interested in creating disaster risk management for their business. Especially, they concern about assets protection.

Our key informants agree that disaster risk management is important for their business and disaster risk management models should be create immediately. They also agree and committed to create joint cooperation of three parties (e.g government institution, financial institution and SME associations) in the implementation of the model. However, there still a debate about detail in disaster risk management model implementation. Our key informants in this FGD agree that local goverment in Surakarta should initate policy in disaster mitigation for MSME in the area. Establishment of Surakarta Board of Disaster Mitigation should be arrange immediately. However, disaster risk awareness should be implanted in MSME business mind set. MSME should developed their own disaster mitigation procedures.

\section{Findings}

1. SME Risk Perceptions and How to Encourage Risk Awareness.

Our finding from two discussions and survey shows that SME does not have perception of disaster risk. They do not consider disaster or any other risks that could happen in the future and gives negative impact to their business. The fact that SME has low income from their operation becomes main reason why they concentrate on surviving their business. For example, most of SME which become our respondents do not have safety procedure in their operations. Our survey shows that most of SME in Surakarta has also experience several disasters in their business. The priorities of disasters that have high possibility of happened in the future are fire, climate change and flood. Most of SME in Surakarta have experience fire as disaster affect their business. The question arise from this finding is how to encourage risk awareness among SME in Surakarta? The problems are who will responsible for accomplish a socialization activity of encouraging risk awareness in SME business operations?

\section{Risk Assessment and Anticipation.}

Our survey and discussions give information about risk assessment for SME disaster risks. We have developed model which contains priorities of asset to protect from disaster risk. Priorities of business impact from disaster are production tool and engine malfunction, factory destroys or malfunction, capital access termination and product failure. Those are factors which need to be protected by risk management. 
We also appraise the frequency or possible frequency from each of disaster risks. Frequency of risks will gives information the correlation of disaster risks with asset to protect.

SME has unique risk anticipation to protect their interests. In general, they use their saving to anticipate business distortion. However, their saving is not specified to protect their assets or interests from disaster risks. Question arise from this finding is how should SME anticipate risks occur from disaster?

\section{Bank Perception of Disaster Risk.}

50 percents of SME in Surakarta has financial debt from commercial banks. This fact increase risk of bad debt among SME due to disaster. Commercial banks consider disaster as force major. This is a reason for bank to accomplish different policy to SME when disaster occurs. These policies include debt rescheduling and debt swap to equity.

Bank BRI experiences of facing bad debt of SME during Merapi eruption show that rescheduling is a possible option. It has no experience of commencing debt swap, but the idea is interesting for the bank.

\section{Institution Involvement}

Our key informant from Kesbanglinmas gives us important information that Surakarta city does not have master plan for disaster risk management for SME. They concentrate on emergency issue on disaster such as rehabilitation and reconstruction of disaster causalities and infrastructure, while economic and business rehabilitation are still ignored.

Surakarta city do not have an institution which specialized in accomplishing disaster mitigation while in Central Java province Badan Penanggulangan Bencana Daerah (BPBD) has been founded. It brings difficulties in coordinating disaster mitigation policy in this city. In order to found such institution the city need legal act in the form of Perda (Peraturan Daerah) and from our examination Surakarta local parliament is still reject to establish such legal act.

\section{Risk Management Procedure}

Our key informant from Sinar Mas Insurance explains about disaster insurance that possible for SME in Surakarta. Low cost insurance is possible as long as SME business association could arrange agreement among SME to join insurance. There is also other possibility of government guarantee to insurance company with APBD to protect SME assets from disaster.

There is also other risk management procedure which could be implemented by SME immediately. It is accomplishing a safety standard operating procedure to prevent disaster caused by human error, such as fire. However, this procedure is not applicable for natural disaster.

\section{Institution Cooperation.}

This is maybe the most important findings from this research. We conclude that it is almost impossible to construct a model of disaster risk management for SME without involving other institution. There should be cooperation between government institutions, financial institutions and SME association. Our key informants from focus group discussions agreed there should be some kind of three parties' cooperation between government institutions, financial institutions and SME associations. The form of this cooperation should be discussed further.

There are three agendas of three parties' cooperation to discuss further. There are disaster risk awareness activities to SME, disaster risk management policy and disaster risk 
mechanism/procedure supported by government institutions, financial institutions and SME associations.

\section{Implications of the Model}

The following model shows procedure and activities choose by SME when disaster risk occurred. There are three kinds of disaster perceived by SME's in Surakarta threatened their business, they are flood, climate change and fire. This perception of disasters based on SME's experience of disruption in their business due to the emergence of it. Based on the previous experience, SME in Surakarta suffered great loss during disaster in the form of fire and floods. Climate change becomes a real business threat since it start to interrupt business planning and execution. For example, our respondents in agrobusiness have several difficulties in planning their plantation it also gives several disruptions in post-harvest management. The impact of disaster to SME business consists of production tool and machinery loss, plant damage, loss of capital acess and product damage. Those impacts are crucial in the sustainability of SME business. Based on SME's previous experience when disaster risk appeared in a form of those damage then they found it hard to recover their business. SME that experienced disasters and their business has interrupted usually rely on government assistance to retrieve their business. SME's in this study located in the disaster risk area, however they do not have disaster mitigation procedures. SMEs arrange their anticipation procedure as general business procedure instead of disaster mitigation procedures eventhough they already experienced business interruption caused by one.

\section{Disaster Impact to SME's Business:}

1. Production tool and machinery loss.

2. Plant/factory damage.

3. Loss of capital access

4 Product damaoe

\begin{tabular}{|l|}
\hline Disaster Risk \\
1. Flood \\
2. Climate \\
Change \\
3. Fire \\
\hline
\end{tabular}

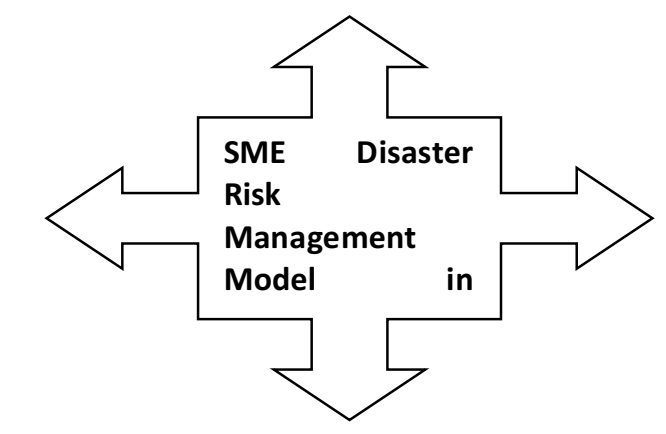

\section{Institutions:}

1. SME Associations.

2. Insurance Companies.

3. Financial Institutions.

4. Government

\section{SME Disaster Risk Anticipation:}

1. Saving from business revenue

2. Developing safety business procedure.

3. Joint cooperation in risk sharing.

4. Buying insurance.

5. Government assistance.

Figure 1: SME's Disaster Risk Management Model 
There are several anticipation procedure anticipated by SME in order to mitigate disaster risk for their business, they are:

Income saving: For SME, saving their income is a way to anticipate uncertainty. Most of SME we interviewed consider disaster is something unpredictable and uncertain. However, they just save some of their income as their capital to recover their business in case disaster risk appeared. This is due to their income is low so that there's not much left after they take their profit to finance their needs.

Developing safety business procedures: SMEs which realize that disaster is a part of their business risk have a consciousness to developed safety business procedure. For example, SME in a flood risk areas will built higher plant or warehouse to prevent product or raw material damages. Often, this consciousness appeared as a result of local wisdom inherited from generation to generation.

Joint cooperation for risk sharing: SME association builds their own disaster risk sharing cooperation among them. The forms of these cooperations are business procedures and common funds collected from member of association periodically. Sometimes, this cooperation has formally institusionalized separate from SME association.

Buying insurance: Several insurance companies have developed disaster risk insurance. However, disaster insurance product for SME has not been issued by those companies, therefore there are only few these business organizations could afford to pay insurance premium. Insurance is not popular among SMEs due to their financial limitations.

Government assistance: Most of SMEs rely on government assistance in their business recovery post disaster. Indonesia's government has policy that assured SME will get immediate support during disaster emergency, nevertheless in time of business recovery stages, this business organizations do not received clear assistance from the government.

\section{Conclusion}

Based on our findings we developed Model of Disaster Risk Management for SME in Surakarta. This model includes type of disaster risk perceived by SME, disaster impact to SME's business, SME's risk management and the role of institution in the model. Figure 1 shows the scheme of SME Disaster Risk Management Model in Surakarta.

Our conclusions in this study are: first, SME should aware that disaster is part of business risk. This awareness should be followed by a development of business procedure that considered disaster as a constraint in their business. Second, there should be formal institution initiated by SME that arrange and maintain risk sharing for disaster.

\section{Acknowledgement}

This research was supported by Australia-Indonesia Facility for Disaster Reduction (AIFDR) AUSAID Indonesia.

\section{References}

Ainuddin,S and J.K. Routray (2012),"Institutional framework, key stakeholders and community preparedness for earthquake induced disaster management in Balochistan," Disaster Prevention and Management, Vol. 21 Iss: 1 pp. 22 - 36, D.O.I : 10.1108/09653561211202683

Alexander, C. (2005), "The present and future of financial risk management," Journal of Financial Econometrics, Vol. 3 No. 1, pp. 3-25. https://doi.org/10.1093/jjfinec/nbi003 
Arnold, M. (2006), "Policy Brief for the Commission on Climate Change and Development The role of risk transfer and insurance in disaster risk reduction and climate change adaptation," ProVention Consortium/IIASA review of microinsurance programs, Disaster Insurance for the Poor? A Review of Microinsurance for Natural Disaster Risks in Developing Countries.

Atmanand, (2003),"Insurance and disaster management: the Indian context," Disaster Prevention and Management, Vol. 12 Iss: 4 pp. 286 - 304.

Cochrane, H. (2004), "Economic loss: myth and Measurement," Disaster Prevention and Management, Volume 13, Number 4, pp. 290-296. https://doi.org/10.1108/09653560410556500

Cooper, C. (2000),"How good are banks at managing business risk?," Balance Sheet, Vol. 8 Iss: 1 pp. 15 - 19. https://doi.org/10.1108/09657960010338418

Doff, R. (2008), "Defining and measuring business risk in an economic-capital framework," The Journal of Risk Finance, Vol. 9, No. 4, pp. 317-333. https://doi.org/10.1108/15265940810894990

Ikhsan, M. (2004), Mengembalikan Laju Pertumbuhan Ekonomi dalam Jangka Menengah: Peran UKM. Jurnal Analisis Sosial. Vol 9 No. 2

Keating .A, Venkateswaran .K, Szoenyi .M, MacClune .K and Mechler .R (2016), From Event Analysis To Global Lessons: Disaster Forensics For Building Resilience, Natural Hazard and Earth System Sciences, Vol 16, pp 1603-1616. https://doi.org/10.5194/nhess-161603-2016

Kumar, T.S.A and J.K. Newport (2007), "Institutional preparedness and sustainability of micro finance institutions during post disaster scenario," Disaster Prevention and Management, Vol. 16 No. 1, pp. 21-32. https://doi.org/10.1108/09653560710729785

Kuritzkes, A. and T. Schuermann (2006), "What we know, don't know and can't know about bank risk: a view from the trenches," in Diebold, F.X. and Herring, R.J. (Eds), The Known, the Unknown and the Unknowable in Financial Risk Management, Princeton University Press, Princeton, NJ. https://doi.org/10.2139/ssrn.887730

Marshall .M.I, Niehm .L.S, Sydnor .S.B and Schrank .H.L, (2015), Predicting Small Business Demise After A Natural Disaster: An Analysis Of Pre-Existing Conditions, Natural Hazards, Vol. 79, pp. 331-354. https://doi.org/10.1007/s11069-015-1845-0

Paradine,R.J (1995), "Business interruption insurance: a vital ingredient in your disaster recovery plan," Information Management \& Computer Security, Vol. 3, No. 1, pp. 9-17. https://doi.org/10.1108/09685229510088223.

Parwito (2011), "200 UKM Rugi Rp 39 Miliar Akibat Letusan Merapi." http://finance.detik.com/read/2011/03/10/174947/1589026/1036/200-ukm-rugi-rp-39miliar-akibat-letusan-merapi access on December 12th 2011.

Paton, D. (2003),"Disaster preparedness: a social-cognitive perspective," Disaster Prevention and Management, Vol. 12, Iss: 3, pp. 210 - 216. https://doi.org/10.1108/09653560310480686

Perry, M. (2007), "Natural disaster management planning A study of logistics managers responding to the tsunami," International Journal of Physical Distribution \& Logistics Management, Vol. 37, No. 5, pp. 409-433. https://doi.org/10.1108/09600030710758455. 
Pinho,J.C. (2007) "The impact of ownership: Location-specific advantages and managerial characteristics on SME foreign entry mode choices," International Marketing Review, Vol. 24 Iss: 6, pp.715 - 734. https://doi.org/10.1108/02651330710832676.

Smith, D. and M. Fischbacher (2009), "The changing nature of risk and risk management: The challenge of borders uncertainty and resilience," Risk Management, no.11, pp. 1 - 12. https://doi.org/10.1057/rm.2009.1

Supyuenyong, V.; N. Islam; U. Kulkarni (2009) "Influence of SME characteristics on knowledge management processes: The case study of enterprise resource planning service providers," Journal of Enterprise Information Management, Vol. 22 Iss: 1/2, pp.63 - 80. https://doi.org/10.1108/17410390910922831.

Tambunan, T. SME development in Indonesia: do economic growth and government supports matter?

Zaitri, C.K. (1996),"Disaster prevention and limitation: state of the art; tools and technologies," Disaster Prevention and Management, Volume 5, Number 1, pp. 30-39. https://doi.org/10.1108/09653569610109541 